\title{
Impact of dietary fiber and immune system stimulation on threonine requirement for protein deposition in growing pigs ${ }^{1}$
}

\author{
Michael O. Wellington, ${ }^{\dagger, \dagger}$ John K. Htoo, ${ }^{\prime}$ Andrew G. Van Kessel, ${ }^{\dagger}$ and Daniel A. Columbus ${ }^{\dagger, \star 2}$ \\ Department of Animal and Poultry Science, University of Saskatchewan, 51 Campus Drive, Saskatoon, SK,

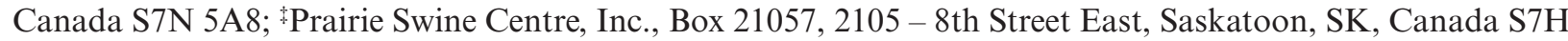 \\ 5N9; and "Evonik Nutrition \& Care GmbH, Rodenbacher Chaussee, Hanau-Wolfgang, Germany
}

\begin{abstract}
High dietary fiber (DF) and immune system stimulation (ISS) are thought to limit amino acid availability for protein deposition (PD) in growing pigs. A nitrogen-balance study was conducted to determine $\mathrm{Thr}$ requirement for optimal PD when DF and ISS were present alone and in combination. A total of 90 barrows $(20.5 \mathrm{~kg}$ initial $\mathrm{BW} ; \mathrm{SD}=0.75 \mathrm{~kg})$ were randomly assigned to one of 10 dietary treatments $(n=9)$ in nine blocks. Diets consisted of a low fiber (LF; $12.5 \%$ total DF) or high fiber (HF; $18.5 \%$ total DF by adding $10 \%$ sugar beet pulp and $5 \%$ wheat bran to the LF diet) with graded levels of $\mathrm{Thr}(0.49 \%$, $0.57 \%, 0.65 \%, 0.73 \%$, and $0.81 \%$ standardized ileal digestible [SID]) fed at $2.2 \times$ maintenance ME requirements. After an 8-d adaptation, two 4-d nitrogen balance collection periods (pre-ISS and ISS) were conducted. ISS was induced by repeated injections (i.m.) of increasing doses of Escherichia coli lipopolysaccharide. Blood samples were taken during both periods to assess acute phase proteins and complete blood cell count. Data were analyzed by PROC MIXED with fixed effects of period,
\end{abstract}

Thr, fiber, and their interactions, with block as a random effect. Nitrogen balance was analyzed separately for each period. Threonine requirement was estimated using PROC NLIN quadratic break-point model. Serum concentration of albumin, haptoglobin, fibrinogen, whole blood white blood cell, and platelet count were affected by ISS $(P<0.001)$ confirming successful ISS. During pre-ISS, PD increased linearly $(P<0.01)$ as Thr concentration in the diet increased, with a significant interaction $(P<0.05)$ between fiber and Thr. During ISS, PD increased linearly $(P<0.05)$ as Thr concentration in the diet increased. Quadratic break-point model estimated SID Thr required to maximize PD of pigs fed LF and HF diets during pre-ISS period was $0.68 \%\left(R^{2}=0.88\right)$ and $0.78 \%$ $\left(R^{2}=0.99\right)$, respectively. During ISS, the SID Thr requirement was estimated at $0.76 \%\left(R^{2}=0.76\right)$ for $\mathrm{LF}$ diet and $0.72 \%\left(R^{2}=0.95\right)$ for HF fed pigs. $\mathrm{HF}$ and ISS independently increased Thr requirement for maximum PD, but these effects were not additive. HF may therefore mask the effects of ISS on Thr requirement for immune response and PD.

Key words: dietary fiber, immune system stimulation, pigs, protein deposition, threonine

(C) The Author(s) 2018. Published by Oxford University Press on behalf of the American Society of Animal Science. All rights reserved. For permissions, please e-mail: journals.permissions@oup.com.

J. Anim. Sci. 2018.96:5222-5232 doi: 10.1093/jas/sky381

\section{INTRODUCTION}

${ }^{1}$ Funding for this project was provided by Alberta Agriculture and Forestry Strategic Research and Development Section, Evonik Nutrition \& Care GmbH, and Mitacs Accelerate.

${ }^{2}$ Corresponding author: dan.columbus@usask.ca

Received June 18, 2018.

Accepted October 4, 2018.
Protein deposition (PD), which represents a balance between synthesis and degradation of proteins, is an important parameter to measure efficiency of protein utilization for growth (Metayer et al., 2008). To maximize whole body PD, it is necessary to determine dietary AA requirements under different environmental and physiological 
conditions. Current production systems expose pigs to varied environmental and physiological stressors, which may provoke immune stimulation. Immune system stimulation (ISS) affects metabolism and utilization of AA by activating immune cells that release cytokines, disrupting normal metabolism, and redirecting AA towards supporting immune response rather than growth (Reeds et al., 1994; Le Floc'h et al., 2004). Threonine is of particular importance during immune challenge for the synthesis of acute phase proteins and immunoglobulins (Reeds and Jahoor, 2001; Li et al., 2007). Furthermore, Thr is abundant in mucins (Munasinghe et al., 2017) which are secreted in response to immune challenge at mucosal surfaces (Rakhshandeh et al., 2013). Although DF plays an essential role in gut health and function (Lindberg, 2014), studies have reported a reduced efficiency in Thr utilization for growth when pigs are fed diets high in DF (Zhu et al., 2005; Libao-Mercado et al., 2006; Mathai et al., 2016). This effect has been linked to increased endogenous protein losses (Jansman et al., 2002) associated with an increase in intestinal mucous secretion (Myrie et al., 2008). The synthesis of mucous is dependent Thr abundance, and under conditions of limited dietary Thr, protein synthesis is conserved in mucin secreting tissues (Munasinghe et al., 2017). The present work was undertaken to quantify the effect of ISS and high DF on Thr requirement for PD and since both ISS and high DF affect different aspects of Thr utilization, we further hypothesize additive effects when both ISS and high DF are present together.

\section{MATERIALS AND METHODS}

The experimental protocol was reviewed and approved by the University of Saskatchewan's Animal Research Ethics Board (AUP 20160107) and followed the Canadian Council on Animal Care guidelines (CCAC, 2009).

\section{Animals, Housing, Diets, and Experimental Design}

A total of 90 growing barrows (Camborough Plus $\times$ C3378: PIC Canada Ltd.) with initial BW of $20.5 ; \mathrm{SD}=0.75 \mathrm{~kg}$ were used in a nitrogen $(\mathbf{N})$ balance study at the Prairie Swine Centre, Inc. (Saskatoon, Canada). Pigs were individually housed in metabolism crates $(1.4 \mathrm{~m} \times 1.5 \mathrm{~m})$ in a temperature-controlled room at $20 \pm 2{ }^{\circ} \mathrm{C}$. Pigs were randomly assigned to one of 10 dietary treatments over nine blocks with a total of 10 pigs per block and nine pigs per treatment. The dietary treatments (Table 1) were arranged as a $2 \times 5$ factorial in a randomized complete block with factors of fiber level [high fiber (HF) or low fiber (LF)] and threonine level $(0.49 \%$, $0.57 \%, 0.65 \%, 0.73 \%$, and $0.81 \%$ standardized ileal digestible [SID]). Wheat-soybean meal-based diets were formulated to meet or exceed nutrient requirements according to NRC (2012) except for Thr. The $\mathrm{HF}$ diets were formulated by partly replacing corn in the LF diet with 5\% wheat bran and 10\% sugar beet pulp (Pieper et al., 2012). The diets were isonitrogenous and isoenergetic and contained celite as an indigestible marker (Lan et al., 2008; Emiola et al., 2009). As ISS has been shown to reduce feed intake, all animals received a restricted intake of $2.2 \times$ maintenance ME requirement (197 kcal $/ \mathrm{kgBW}^{0.60}$; NRC, 2012) throughout the study (Litvak et al., 2013; Rudar et al., 2016). Feed was offered in two equal meals at 0800 hours and 1500 hours with ad libitum access to water. Feed orts were collected for each pig daily and weighed to determine actual daily feed intake. The experimental period was a total of $16 \mathrm{~d}$ in duration and consisted of an 8-d adaptation period followed by two 4-d collection periods, a pre-ISS period and an ISS period. ISS was achieved by i.m. injection of Escherichia coli lipopolysaccharide (LPS; O55:B5, Sigma Aldrich, Oakville, ON, Canada) at an initial dosage of $30 \mu \mathrm{g} / \mathrm{kg}$ BW given on day 1 of the ISS period, at least $1 \mathrm{~h}$ before the morning meal. A second injection was given $48 \mathrm{~h}$ later with the dose increased by $15 \%$ to counteract the possibility of tolerance (Rakhshandeh and de Lange, 2012).

\section{Blood Sampling and Rectal Temperature Measurement}

Blood samples were taken from all pigs during pre-ISS and ISS periods $3 \mathrm{~h}$ after the morning meal. On the first day of pre-ISS period, two blood samples were collected into $10 \mathrm{~mL}$ tubes from each pig via jugular puncture. Similarly, two blood samples from each pig were collected on the first day of ISS period, $4 \mathrm{~h}$ after LPS injection. The vacutainer collection tubes either contained EDTA or no additive (BD, Vacutainers Mississauga, ON, Canada). Blood samples in EDTA-coated tubes were immediately submitted for complete blood cell and fibrinogen analysis (Prairie Diagnostic Services, Saskatoon, Canada). Samples collected in additive-free tubes were allowed to clot and centrifuged at $2,500 \times g$ at $4{ }^{\circ} \mathrm{C}$ for $15 \mathrm{~min}$. Serum samples were collected and stored at $-20^{\circ} \mathrm{C}$. Rectal temperature was monitored on days 1 and 3 during both preISS and ISS periods ( $4 \mathrm{~h}$ post-LPS injection during 
the ISS period and same time line during pre-ISS period) using a digital thermometer.

\section{Nitrogen Balance}

During each N-balance period, fresh fecal grab samples were collected daily for each pig and stored at $-20{ }^{\circ} \mathrm{C}$. At the end of the experiment, fecal samples were thawed, pooled for each pig in each N-balance period, and homogenized. Subsamples were taken and stored at $-20^{\circ} \mathrm{C}$ until further analysis. Urine samples were collected quantitatively daily during each N-balance period for each pig using collection jars placed under the metabolism crates for each $24-\mathrm{h}$ period. Urine collection jars contained sufficient quantities of $6 \mathrm{~N} \mathrm{HCl}$ to maintain urine $\mathrm{pH}$ below 3 to reduce $\mathrm{N}$ losses through ammonia volatilization (de Lange et al., 2001). At the end of each $24 \mathrm{~h}$ urine collection, urine was weighed, and a 10\% aliquot sampled per pig. All urine samples were pooled for each pig per period and stored at $-20{ }^{\circ} \mathrm{C}$ until further analysis.

\section{Analytical Procedures}

Diet samples were analyzed for AA composition using ion-exchange chromatography with post-column derivatization with ninhydrin (Evonik Nutrition \& Care $\mathrm{GmbH}$, Hanau, Germany; Llames and Fontaine, 1994). Fecal samples were dried in a force air draft oven at $55^{\circ} \mathrm{C}$ for $72 \mathrm{~h}$ before grinding in a centrifugal mill (ZM 100, RETSCH GmbH \& Co. Rheinische Straße, Germany) through a 1-mm sieve. The dry matter (DM) content of the diets and fecal samples was measured in duplicate by the method 930.15 (AOAC, 2007). Nitrogen content was determined in diet, fecal, and urine samples using an automatic analyzer (LECO FP 528; MI; Method 990.03; AOAC, 2007). The gross energy content of the diets was analyzed by bomb calorimeter (6400 automatic Isoperibol system, Parr Instruments Company, IL). Total fiber (TDF), soluble dietary fiber, and insoluble dietary fiber of the complete diets was analyzed according to the AOAC (2007) method 991.43 using an ANKOM $^{\mathrm{TDF}}$ DF analyzer (ANKOM Technology, Macedon NY). Acid insoluble ash content of the diets and fecal samples were measured in triplicates and duplicates, respectively, according to methods described by Van Keulen and Young (1977). Complete blood cell count was analyzed at Prairie Diagnostic Services (Saskatoon, SK, Canada) using an ADVIA 2120i hematology analyzer (Siemens Health Care Diagnostics, Deerfield, IL). Fibrinogen was analyzed by heat precipitate and refractometer method and serum albumin analyzed by bromocresol green method using a Cobas C 311 (Roche Diagnostics) according to Doumas et al. (1971). Serum haptoglobin was analyzed in the Animal Health Laboratory (University of Guelph, Guelph, ON) according to a method described by Makimura and Suzuki (1982) on a Roche Cobas 6000 c501 analyzer.

\section{Calculations}

Apparent total tract digestibility of DM and $\mathrm{N}$ were determined using the indicator method according to the following equation:

$$
\mathrm{N} \text { digestibility }=100-\left[\frac{I_{\mathrm{D}} \times N_{\mathrm{F}}}{I_{\mathrm{F}} \times N_{\mathrm{D}}}\right] \times 100 \%
$$

where $I_{\mathrm{D}}$ and $I_{\mathrm{F}}$ are the indicator concentration in the diet and feces, respectively. $N_{\mathrm{D}}$ and $N_{\mathrm{F}}$ are the nitrogen concentration in the diet and feces, respectively. Nitrogen retention $(\mathrm{g} / \mathrm{d})$ was calculated as the difference between total $\mathrm{N}$ intake $(\mathrm{g} / \mathrm{d})$ and total $\mathrm{N}$ losses (urine and fecal $\mathrm{N}$ output; g/d). Whole-body $\mathrm{PD}(\mathrm{g} / \mathrm{d})$ was calculated as $\mathrm{N}$ retained $\times 6.25$.

\section{Statistical Analysis}

Statistical analyses were conducted using the MIXED model procedure of SAS (version 9.4; SAS Institute, Inc. Cary, NC). Normality of the data was verified, and outliers were tested using the UNIVARIATE procedure of SAS. Data for blood parameters were analyzed with dietary threonine ( $n=5$; fixed effect), fiber level ( $n=2$; fixed effect), period ( $n=2$; fixed effect), and block $(n=9)$ as a random effect. For the N-balance data, analysis was completed separately for each period with fiber level ( $n=2$; fixed effect), Thr level ( $n=5$; fixed effect), and block ( $n=9$; random effect) as well as the interactions between fiber and Thr included in the model as sources of variation. Orthogonal polynomial contrast statements were defined for each N-balance period to determine linear and quadratic effects of dietary Thr concentration on PD. The quadratic break-point model was used (PROC NLIN) to estimate Thr requirement. The Tukey mean separation test was used to determine differences between means and significance level was defined as $P<0.05$. A trend towards significance was considered at $P \leq 0.10$.

\section{RESULTS AND DISCUSSION}

\section{General Observations}

Pigs were generally healthy throughout the experiment and consumed their daily feed 
Table 1. Composition of experimental diets with extreme threonine levels (as-fed basis) ${ }^{1}$

\begin{tabular}{|c|c|c|c|c|}
\hline \multirow[b]{3}{*}{ Ingredients, $\%$} & \multicolumn{4}{|c|}{$\mathrm{SID}^{2}$ threonine, $\%$} \\
\hline & \multicolumn{2}{|c|}{ Low fiber } & \multicolumn{2}{|c|}{ High fiber } \\
\hline & 0.49 & 0.81 & 0.49 & 0.81 \\
\hline Corn & 22.0 & 21.7 & 4.3 & 4.0 \\
\hline Barley & 7.0 & 7.0 & 7.0 & 7.0 \\
\hline Wheat & 48.0 & 48.0 & 48.0 & 48.0 \\
\hline Soybean meal & 18.2 & 18.2 & 18.5 & 18.5 \\
\hline Wheat bran & - & - & 5.0 & 5.0 \\
\hline Sugar beet pulp & - & - & 10.0 & 10.0 \\
\hline Canola oil & 1.20 & 1.20 & 3.80 & 3.80 \\
\hline L-Lys $-\mathrm{HCl}^{3}$ & 0.58 & 0.58 & 0.56 & 0.56 \\
\hline DL-Met ${ }^{3}$ & 0.20 & 0.20 & 0.20 & 0.20 \\
\hline L-Trp ${ }^{3}$ & 0.04 & 0.04 & 0.03 & 0.03 \\
\hline $\mathrm{L}-\mathrm{Val}^{3}$ & 0.09 & 0.09 & 0.09 & 0.09 \\
\hline L-Leu ${ }^{3}$ & - & - & 0.07 & 0.07 \\
\hline L-Thr ${ }^{3}$ & 0.00 & 0.33 & 0.00 & 0.33 \\
\hline Limestone & 1.25 & 1.25 & 1.05 & 1.05 \\
\hline Monocalcium phosphate & 0.75 & 0.75 & 0.71 & 0.71 \\
\hline Salt & 0.20 & 0.20 & 0.20 & 0.20 \\
\hline Vitamin-mineral premix ${ }^{4}$ & 0.10 & 0.10 & 0.10 & 0.10 \\
\hline Celite & 0.40 & 0.40 & 0.40 & 0.40 \\
\hline \multicolumn{5}{|l|}{ Calculated nutrient content ${ }^{5}$} \\
\hline $\mathrm{ME}, \mathrm{MJ} / \mathrm{kg}$ & 13.9 & 13.9 & 14.0 & 14.0 \\
\hline $\mathrm{NE}, \mathrm{MJ} / \mathrm{kg}$ & 10.5 & 10.5 & 10.5 & 10.5 \\
\hline CP, $\%$ SID & 17.3 & 17.5 & 17.7 & 17.9 \\
\hline Thr, \% SID & 0.49 & 0.81 & 0.49 & 0.81 \\
\hline Lys, \% SID & 1.12 & 1.12 & 1.12 & 1.12 \\
\hline Met+Cys, $\%$ SID & 0.68 & 0.68 & 0.68 & 0.68 \\
\hline Val, $\%$ SID & 0.75 & 0.75 & 0.75 & 0.75 \\
\hline Trp, \% SID & 0.22 & 0.22 & 0.22 & 0.22 \\
\hline Ile, \% SID & 0.59 & 0.59 & 0.59 & 0.59 \\
\hline Leu, $\%$ SID & 1.12 & 1.12 & 1.12 & 1.12 \\
\hline
\end{tabular}

${ }^{1}$ The experimental diets with the intermediate $\mathrm{Thr}(0.57 \%, 0.65 \%$, and $0.73 \%$ SID) were prepared by blending the $0.49 \%$ and $0.81 \%$ SID diets in appropriate proportions.

${ }^{2} \mathrm{SID}=$ standardized ileal digestible.

${ }^{3}$ Supplied by Evonik Nutrition and Care GmbH (Hanau-Wolfgang, Germany).

${ }^{4}$ Supplied per kg of complete diet: vitamin A, 8,000 IU; vitamin D, 1,500 IU; vitamin E, $30 \mathrm{IU}$; menadione, $2.5 \mathrm{mg}$; vitamin B12, $0.025 \mathrm{mg}$; thiamine, $1.00 \mathrm{mg}$; biotin, $0.10 \mathrm{mg}$; niacin, $20 \mathrm{mg}$; riboflavin, $4 \mathrm{mg}$; pantothenate; $12 \mathrm{mg}$; folic acid, $0.50 \mathrm{mg}$; pyridoxine, $2.0 \mathrm{mg}$; Fe, $100 \mathrm{mg}$; Zn, $100 \mathrm{mg}$; Mg, $40 \mathrm{mg}$; Cu, $15 \mathrm{mg}$; Se, $0.30 \mathrm{mg}$; and I, $1 \mathrm{mg}$.

${ }^{5}$ Nutrient content of diets based on nutrient content of feed ingredients according to NRC (2012).

allocations readily during the pre-ISS period. During the ISS period, the initial LPS injection generated a significant clinical response in pigs including signs of lethargy, feed refusal for some hours, and vomiting. Vomitus collected for each pig was included in the feed refusal for that day. The second injection did not result in any further observable clinical signs indicating development of tolerance to the LPS (Rakhshandeh and de Lange, 2012). Five pigs were removed $[\operatorname{LF}(0.49,0.73$, and 0.57 SID Thr levels) and HF (0.73 and 0.49 SID Thr levels)] from the experiment due to incomplete urine and/or fecal collection. Analyzed and calculated nutrient content of experimental diets is presented in Table 2. TDF content was higher $(18.5 \%)$ in the HF diets than LF $(12.5 \%)$ diets (see Table 2). The total indispensable analyzed and calculated AA contents of the experimental diets where similar across diets. The minor differences are likely due to inherent inaccuracies in ingredient and diet sampling, diet preparation, and AA analysis (Rutherford and Moughan, 2000).

\section{Response to LPS Challenge}

In the present study, repeated i.m. injection of LPS was selected as a non-infectious immune challenge model as previously reported (de Ridder et al., 
Table 2. Analyzed nutrient composition of the experimental diets (as-is basis)

\begin{tabular}{|c|c|c|c|c|c|c|c|c|c|c|}
\hline \multirow[b]{3}{*}{ Item } & \multicolumn{10}{|c|}{ SID $^{1}$ threonine, $\%$} \\
\hline & \multicolumn{5}{|c|}{ Low fiber } & \multicolumn{5}{|c|}{ High fiber } \\
\hline & 0.49 & 0.57 & 0.65 & 0.73 & 0.81 & 0.49 & 0.57 & 0.65 & 0.73 & 0.81 \\
\hline Gross energy, MJ/kg & 16.60 & 16.49 & 16.48 & 16.59 & 16.66 & 17.16 & 17.14 & 17.34 & 17.25 & 17.20 \\
\hline Dry matter, \% & 88.50 & 88.14 & 89.72 & 88.29 & 88.35 & 88.77 & 88.57 & 88.96 & 88.79 & 88.44 \\
\hline $\mathrm{CP}, \%$ & 19.69 & 18.33 & 19.14 & 19.46 & 18.71 & 18.73 & 18.62 & 19.29 & 18.97 & 18.85 \\
\hline $\mathrm{TDF}^{2}, \%$ & 12.47 & 12.25 & 12.00 & 12.86 & 12.54 & 17.80 & 18.21 & 17.95 & 18.72 & 18.93 \\
\hline $\mathrm{SDF}^{3}, \%$ & 1.16 & 0.95 & 0.68 & 0.73 & 0.99 & 1.97 & 2.12 & 2.35 & 2.87 & 2.77 \\
\hline $\mathrm{IDF}^{4}, \%$ & 11.31 & 11.30 & 11.25 & 12.13 & 11.54 & 14.50 & 16.09 & 15.60 & 15.84 & 16.16 \\
\hline \multicolumn{11}{|c|}{ Total amino acids $5, \%$} \\
\hline Lys & $1.23(1.21)$ & $1.25(1.21)$ & $1.25(1.21)$ & $1.25(1.21)$ & $1.23(1.21)$ & $1.20(1.22)$ & $1.20(1.22)$ & $1.25(1.22)$ & $1.25(1.22)$ & $1.28(1.22)$ \\
\hline Met & $0.42(0.45)$ & $0.40(0.45)$ & $0.45(0.45)$ & $0.44(0.45)$ & $0.44(0.45)$ & $0.45(0.44)$ & $0.45(0.44)$ & $0.46(0.44)$ & $0.45(0.44)$ & $0.44(0.44)$ \\
\hline Met+Cys & $0.74(0.75)$ & $0.72(0.75)$ & $0.76(0.75)$ & $0.76(0.75)$ & $0.76(0.75)$ & $0.76(0.76)$ & $0.76(0.76)$ & $0.78(0.76)$ & $0.76(0.76)$ & $0.74(0.76)$ \\
\hline Thr & $0.64(0.60)$ & $0.67(0.66)$ & $0.74(0.74)$ & $0.80(0.82)$ & $0.86(0.90)$ & $0.64(0.60)$ & $0.67(0.67)$ & $0.75(0.75)$ & $0.82(0.83)$ & $0.89(0.90)$ \\
\hline $\operatorname{Trp}$ & $0.26(0.25)$ & $0.25(0.25)$ & $0.26(0.25)$ & $0.27(0.25)$ & $0.26(0.25)$ & $0.25(0.25)$ & $0.26(0.25)$ & $0.27(0.25)$ & $0.27(0.25)$ & $0.26(0.25)$ \\
\hline Arg & $1.09(1.02)$ & $1.02(1.02)$ & $1.07(1.02)$ & $1.06(1.02)$ & $1.04(1.02)$ & $1.04(1.03)$ & $1.04(1.03)$ & $1.07(1.03)$ & $1.07(1.03)$ & $1.07(1.03)$ \\
\hline Ile & $0.70(0.66)$ & $0.68(0.66)$ & $0.70(0.66)$ & $0.70(0.66)$ & $0.69(0.66)$ & $0.68(0.67)$ & $0.68(0.67)$ & $0.69(0.67)$ & $0.70(0.67)$ & $0.70(0.67)$ \\
\hline Leu & $1.36(1.26)$ & $1.30(1.26)$ & $1.34(1.26)$ & $1.34(1.26)$ & $1.31(1.26)$ & $1.29(1.27)$ & $1.30(1.27)$ & $1.33(1.27)$ & $1.33(1.27)$ & $1.32(1.27)$ \\
\hline Val & $0.89(0.82)$ & $0.84(0.82)$ & $0.87(0.82)$ & $0.88(0.82)$ & $0.86(0.82)$ & $0.88(0.85)$ & $0.87(0.85)$ & $0.89(0.85)$ & $0.90(0.85)$ & $0.90(0.85)$ \\
\hline His & $0.44(0.41)$ & $0.42(0.41)$ & $0.44(0.41)$ & $0.44(0.41)$ & $0.43(0.41)$ & $0.43(0.42)$ & $0.43(0.42)$ & $0.44(0.42)$ & $0.44(0.42)$ & $0.44(0.42)$ \\
\hline Phe & $0.88(0.79)$ & $0.84(0.79)$ & $0.87(0.79)$ & $0.86(0.79)$ & $0.85(0.79)$ & $0.83(0.79)$ & $0.84(0.79)$ & $0.85(0.79)$ & $0.85(0.79)$ & $0.85(0.79)$ \\
\hline
\end{tabular}

${ }^{1}$ SID $=$ standardized ileal digestible.

${ }^{2} \mathrm{TDF}=$ total dietary fiber.

${ }^{3} \mathrm{SDF}=$ soluble dietary fiber.

${ }^{4} \mathrm{IDF}=$ insoluble dietary fiber.

${ }^{5}$ Analyzed values of total amino acids with calculated values in brackets.

2012; Litvak et al., 2013). Taken together, the marked clinical observations, increased $(P<0.01)$ rectal temperature (Fig. 1) and decreased white blood cell counts $(P<0.001)$, and major serum proteins $(P<0.05)$ measured after LPS injection (Table 3$)$, all indicate effective stimulation of an acute inflammatory response. Acute leukopenia $(P<0.001)$ and a marked reduction $(P<0.001)$ in peripheral platelet count probably resulted from acute extravasation into tissues as has been observed by others following LPS injection in the pig (Kluess et al. 2015; Kvidera et al., 2017). Similarly, a reduction $(P<0.001)$ in serum albumin levels in this study has also been reported by others following LPS in pigs (de Ridder et al., 2012; Litvak et al., 2013; Christoffersen et al., 2015). Haptoglobin concentration decreased $(P<0.05)$ within $4 \mathrm{~h}$ of intramuscular LPS injection in the present study, which was surprising although possibly also related to acute capillary extravasation and the relatively short period between LPS administration and blood sampling. Others have reported an increase (Christoffersen et al., 2015) or no change (Gabay and Kushner, 1999) in haptoglobin levels following LPS administration.

Reports suggest that the concentration of these acute phase proteins increase $8 \mathrm{~h}$ after ISS and may remain elevated for about $24 \mathrm{~h}$ (Heegaard

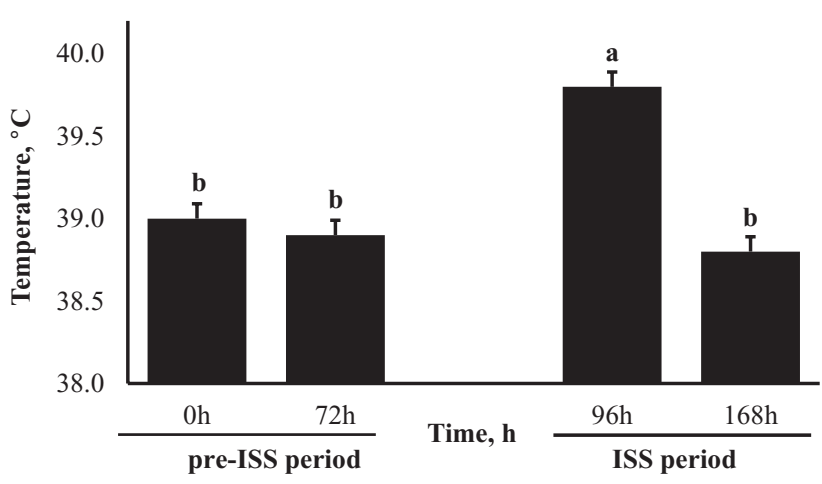

Figure 1. Rectal temperature measured at time 0 and $72 \mathrm{~h}$ (pre-immune system stimulation [ISS] period) and 96 and $168 \mathrm{~h}$ (ISS period). Escherichia coli lipopolysaccharide was administered intramuscularly at 92 and $140 \mathrm{~h}$. Values without a common superscript are significantly different $(P<0.001)$.

et al., 1998; Hulten at al., 2003; Gruys et al., 2005). Increased $(P<0.05)$ fibrinogen concentration during the ISS period in the present study agrees with other studies (de Ridder et al., 2012; Litvak et al., 2013) although the fibrinogen response to LPS observed here was variable (Table 3). To compensate for the expected development of tolerance to LPS (Rakhshandeh and de Lange, 2012), the second dose of LPS was increased by 15\% (Rudar et al., 2016). Despite this increase in dose, no obvious clinical signs were observed following the 
Table 3. Plasma concentration of selected proteins and white blood cell (WBC) count ${ }^{1,2}$

\begin{tabular}{|c|c|c|c|c|c|c|c|c|c|c|c|c|c|c|}
\hline \multirow[b]{3}{*}{ Items } & \multicolumn{10}{|c|}{$\mathrm{SID}^{7}$ threonine, $\%$} & & & & \\
\hline & \multicolumn{2}{|c|}{0.49} & \multicolumn{2}{|c|}{0.57} & \multicolumn{2}{|c|}{0.65} & \multicolumn{2}{|c|}{0.73} & \multicolumn{2}{|c|}{0.81} & \multicolumn{4}{|c|}{$P$-value ${ }^{4}$} \\
\hline & $\mathrm{LF}^{5}$ & $\mathrm{HF}^{6}$ & $\mathrm{LF}$ & $\mathrm{HF}$ & $\mathrm{LF}$ & $\mathrm{HF}$ & $\mathrm{LF}$ & $\mathrm{HF}$ & $\mathrm{LF}$ & $\mathrm{HF}$ & SEM & Period & Fiber & Thr \\
\hline \multicolumn{15}{|c|}{$\mathrm{WBC}, \times 10^{9} / \mathrm{L}$} \\
\hline Pre-ISS & 24.8 & 20.5 & 20.5 & 19.9 & 20.6 & 20.9 & 22.9 & 22.3 & 25.8 & 20.1 & 1.40 & $<.0001$ & 0.088 & 0.477 \\
\hline ISS & 4.5 & 4.8 & 4.4 & 4.9 & 4.3 & 5.1 & 5.2 & 3.9 & 4.6 & 4.9 & & & & \\
\hline \multicolumn{15}{|c|}{ Platelets, $\times 10^{9} / \mathrm{L}$} \\
\hline Pre-ISS & 402.7 & 322.2 & 412.7 & 438.1 & 372.8 & 368.4 & 386.0 & 373.6 & 348.9 & 347.6 & 40.9 & $<.0001$ & 0.558 & 0.08 \\
\hline ISS & 213.9 & 204.5 & 259.8 & 259.2 & 185.4 & 229.4 & 313.2 & 232.6 & 190.6 & 204.4 & & & & \\
\hline \multicolumn{15}{|c|}{ Albumin, g/L } \\
\hline Pre-ISS & 38.8 & 36.0 & 37.0 & 37.0 & 38.3 & 36.4 & 40.7 & 38.2 & 39.7 & 39.1 & 1.10 & $<.0001$ & $<0.05$ & $<0.05$ \\
\hline ISS & 35.9 & 32.5 & 34.3 & 34.3 & 34.2 & 32.8 & 37.5 & 34.7 & 34.9 & 36.7 & & & & \\
\hline \multicolumn{15}{|c|}{ Haptoglobin, g/L } \\
\hline Pre-ISS & 0.64 & 0.66 & 0.49 & 0.54 & 0.64 & 0.85 & 0.78 & 0.54 & 0.72 & 0.58 & 0.17 & $<0.05$ & 0.985 & 0.749 \\
\hline ISS & 0.60 & 0.34 & 0.39 & 0.58 & 0.38 & 0.54 & 0.65 & 0.56 & 0.34 & 0.46 & & & & \\
\hline \multicolumn{15}{|c|}{ Fibrinogen, $g / L$} \\
\hline Pre-ISS & 2.7 & 1.3 & 2.1 & 1.5 & 2.4 & 1.8 & 2.6 & 2.1 & 1.3 & 1.2 & 0.32 & $<0.05$ & $<0.05$ & $<.0001$ \\
\hline ISS & 2.3 & 1.4 & 3.9 & 2.6 & 2.9 & 1.8 & 3.1 & 1.8 & 2.3 & 2.4 & & & & \\
\hline
\end{tabular}

${ }^{1}$ Immune system stimulation (ISS) was achieved by injecting increasing doses of $E$. coli lipopolysaccharide on day 1 of ISS at $30 \mu \mathrm{g} / \mathrm{kg}$ BW and $48 \mathrm{~h}$ after with $15 \%$ increase from initial dose.

${ }^{2}$ The data presented are least-square means with standard error of means (SEM) and based on blood samples taken before ISS and $4 \mathrm{~h}$ after ISS initiation $(n=9)$.

${ }^{4}$ No significant interactions were observed.

${ }^{5} \mathrm{LF}=$ low fiber diet.

${ }^{6} \mathrm{HF}=$ high fiber diet.

${ }^{7} \mathrm{SID}=$ standardized ileal digestible.

second dose suggesting the increase in dose did not fully compensate for tolerance.

\section{Nitrogen Balance in Response to DF and Threonine Dose}

The use of co-products has been increasing in swine production, and these products tend to increase the fiber content in swine diets. Fibrous ingredients will increase digesta passage rate and microbial activity in the hindgut (Lindberg, 2014). According to Stein et al. (1999), Thr is highly present in endogenous AA losses, and Zhu et al. (2005) therefore suggested that increasing fiber contents in swine diets will increase the requirement for Thr in growing pigs. Mathai et al. (2016) have shown that when DF content is increased, Thr:Lys ratio increased for optimal growth in pigs fed a cornsoybean meal diet. Therefore, the present study evaluated individually the effects of high DF and ISS on PD and these effects were also combined to test their additivity on PD.

When no ISS was present, $\mathrm{N}$ intake showed a significant interaction $(P<0.05$; Table 4$)$ between fiber level and Thr concentration, with total $\mathrm{N}$ intake increasing as Thr intake increased in both LF and HF diets $(P<0.0001)$. High DF increased
$(P<0.0001)$ fecal $\mathrm{N}$ output, an observation consistent with other studies and representing a shift in $\mathrm{N}$ excretion from urine to feces (Dilger et al., 2004; Libao-Mercado et al., 2006). This is confirmed by the decrease in urine $\mathrm{N}$ output in HF fed pigs compared with pigs fed LF diets $(P<0.05)$. Regardless of DF level, as Thr concentration in the diet increased, $N$ output in urine decreased, an indication of increased $\mathrm{N}$ utilization. Apparent total tract digestibility of $\mathrm{N}$ was lower $(P<0.0001)$ in pigs fed the HF diet than in pigs fed the LF diets, which confirms earlier reports on the negative effect of fiber on $\mathrm{N}$ digestibility (Knudsen and Hansen, 1991; Stein et al., 1999; Knudsen et al., 2012). There was a significant interaction $(P<0.05)$ between DF and dietary Thr on PD. Generally, as dietary Thr increased, PD increased in both HF and LF diets; however, the rate of increase was reduced in pigs fed HF diets compared to pigs fed LF diets and suggests that requirement for Thr may be greater in HF than in LF diets. This confirms earlier reports (Myrie et al., 2008; Mathai et al., 2016), suggesting that high DF reduces $\mathrm{N}$ retention and PD. This has been shown to be due to fiber-associated Thr losses, which depends on the fiber source and the concentration in the diet (Blank et al., 2012). In the present study, wheat bran and sugar beet pulp were used as 
Table 4. Nitrogen (N) balance and PD for low fiber (LF) high fiber (HF) diets during the pre-immune stimulation period ${ }^{1}$

\begin{tabular}{|c|c|c|c|c|c|c|c|c|c|c|}
\hline \multirow[b]{2}{*}{ Items } & & \multicolumn{5}{|c|}{$\mathrm{SID}^{4}$ threonine, $\%$} & \multirow[b]{2}{*}{ SEM } & \multicolumn{3}{|c|}{$P$-value } \\
\hline & & 0.49 & 0.57 & 0.65 & 0.73 & 0.81 & & Fiber & Thr & Fiber $\times$ Thr \\
\hline \multirow[t]{2}{*}{ Initial BW, kg } & $\mathrm{LF}$ & 24.1 & 25.2 & 24.8 & 25.2 & 24.9 & 0.40 & 0.489 & 0.186 & 0.136 \\
\hline & $\mathrm{HF}$ & 24.9 & 24.8 & 25.4 & 24.5 & 25.3 & & & & \\
\hline \multirow[t]{2}{*}{$\mathrm{N}$ intake, $\mathrm{g} / \mathrm{d}$} & LF & 25.9 & 28.6 & 27.5 & 28.3 & 26.9 & 0.25 & $<0.05$ & $<0.0001$ & $<0.001$ \\
\hline & $\mathrm{HF}$ & 26.8 & 26.3 & 27.7 & 27.1 & 27.1 & & & & \\
\hline \multirow[t]{2}{*}{ Fecal $\mathrm{N}$ output, g/d } & $\mathrm{LF}$ & 3.5 & 4.3 & 3.5 & 3.9 & 3.8 & 0.17 & $<0.0001$ & 0.139 & $<0.05$ \\
\hline & $\mathrm{HF}$ & 4.2 & 3.9 & 4.1 & 4.3 & 4.4 & & & & \\
\hline \multirow[t]{2}{*}{ Urinary $\mathrm{N}$ output, $\mathrm{g} / \mathrm{d}$} & $\mathrm{LF}$ & 3.2 & 3.3 & 2.5 & 2.1 & 1.9 & 0.35 & $<0.05$ & $<0.0001$ & 0.479 \\
\hline & $\mathrm{HF}$ & 3.1 & 2.2 & 2.6 & 1.5 & 1.4 & & & & \\
\hline \multirow[t]{2}{*}{ ATTD $^{2} \mathrm{~N}, \%$} & $\mathrm{LF}$ & 84.9 & 86.5 & 87.3 & 86.3 & 86.1 & 0.61 & $<0.0001$ & 0.105 & 0.102 \\
\hline & $\mathrm{HF}$ & 84.1 & 85.2 & 85.2 & 84.1 & 83.7 & & & & \\
\hline \multirow[t]{2}{*}{$\mathrm{N}$ retained, $\mathrm{g} / \mathrm{d}$} & $\mathrm{LF}$ & 19.2 & 21.0 & 21.5 & 22.4 & 21.3 & 0.45 & 0.148 & $<0.0001$ & $<0.05$ \\
\hline & $\mathrm{HF}$ & 19.5 & 20.3 & 21.0 & 21.3 & 21.3 & & & & \\
\hline \multirow[t]{2}{*}{$\mathrm{PD}^{3}, \mathrm{~g} / \mathrm{d}$} & $\mathrm{LF}$ & 120.1 & 131.4 & 134.4 & 139.7 & 133.1 & 2.81 & 0.148 & $<0.0001$ & $<0.05$ \\
\hline & $\mathrm{HF}$ & 121.6 & 126.6 & 131.4 & 132.9 & 133.3 & & & & \\
\hline
\end{tabular}

${ }^{1}$ Data presented are least-square means with standard error of means (SEM) and represent measurements taken before ISS ( $n=8$ to 9).

${ }^{2} \mathrm{ATTD}=$ apparent total tract digestibility.

${ }^{3} \mathrm{PD}=$ protein deposition $(\mathrm{N}$ retained $\times 6.25)$.

${ }^{4}$ SID $=$ standardized ileal digestible.

a source of insoluble and soluble fiber, respectively, which have been reported to contribute to endogenous Thr losses due to an increase in mucosal protein synthesis, particularly mucins which are rich in Thr (Zhu et al., 2005; Libao-Mercado et al., 2006, 2007; Blank et al., 2012).

During the ISS period, $\mathrm{N}$ intake and urinary $\mathrm{N}$ output were not affected $(P>0.05$; Table 5$)$ by dietary Thr concentration or fiber level. Fecal N output, however, increased $(P<0.05)$ in pigs fed HF diets but was not affected by dietary Thr level $(P>0.05)$. This is similar to observations made when no ISS was present. Nitrogen retained and PD were affected $(P<0.05)$ by dietary Thr concentration, such that as dietary Thr increased, PD increased linearly. There was no significant effect

Table 5. Nitrogen (N) balance and PD for low fiber (LF) and high fiber (HF) diets during the immune stimulation period ${ }^{1}$

\begin{tabular}{|c|c|c|c|c|c|c|c|c|c|c|}
\hline \multirow[b]{2}{*}{ Items } & & \multicolumn{5}{|c|}{ SID $^{4}$ threonine, $\%$} & \multirow[b]{2}{*}{ SEM } & \multicolumn{3}{|c|}{$P$-value } \\
\hline & & 0.49 & 0.57 & 0.65 & 0.73 & 0.81 & & Fiber & Thr & Fiber $\times$ Thr \\
\hline \multirow[t]{2}{*}{ Initial BW, kg } & $\mathrm{LF}$ & 25.2 & 26.7 & 25.9 & 26.2 & 26.2 & 0.40 & 0.195 & 0.154 & 0.129 \\
\hline & $\mathrm{HF}$ & 26.1 & 26.1 & 26.7 & 25.8 & 26.6 & & & & \\
\hline \multirow[t]{2}{*}{ N Intake, g/d } & $\mathrm{LF}$ & 24.8 & 27.1 & 25.9 & 27.2 & 25.6 & 0.58 & 0.236 & 0.050 & 0.053 \\
\hline & $\mathrm{HF}$ & 25.8 & 25.7 & 27.1 & 26.9 & 27.3 & & & & \\
\hline \multirow[t]{2}{*}{ Fecal N output, g/d } & $\mathrm{LF}$ & 4.1 & 3.8 & 3.7 & 3.8 & 3.6 & 0.25 & $<0.05$ & 0.999 & 0.339 \\
\hline & $\mathrm{HF}$ & 4.2 & 3.9 & 4.3 & 4.2 & 4.4 & & & & \\
\hline \multirow[t]{2}{*}{ Urinary $\mathrm{N}$ output, g/d } & $\mathrm{LF}$ & 3.3 & 2.7 & 2.9 & 2.4 & 2.2 & 0.40 & 0.428 & 0.275 & 0.183 \\
\hline & $\mathrm{HF}$ & 3.6 & 2.4 & 2.9 & 2.9 & 2.5 & & & & \\
\hline \multirow[t]{2}{*}{ ATTD $^{2} \mathrm{~N}, \%$} & $\mathrm{LF}$ & 84.7 & 84.9 & 85.5 & 85.9 & 86.1 & 0.82 & $<0.05$ & 0.894 & 0.717 \\
\hline & $\mathrm{HF}$ & 83.9 & 84.7 & 84.2 & 84.5 & 83.9 & & & & \\
\hline \multirow[t]{2}{*}{$\mathrm{N}$ retained, $\mathrm{g} / \mathrm{d}$} & $\mathrm{LF}$ & 18.3 & 19.6 & 19.3 & 21.1 & 19.8 & 0.63 & 0.705 & $<0.05$ & 0.102 \\
\hline & $\mathrm{HF}$ & 17.9 & 19.3 & 19.9 & 19.9 & 20.4 & & & & \\
\hline \multirow[t]{2}{*}{$\mathrm{PD}^{3}, \mathrm{~g} / \mathrm{d}$} & $\mathrm{LF}$ & 114.4 & 122.7 & 120.9 & 131.4 & 123.9 & 3.95 & 0.725 & $<0.05$ & 0.539 \\
\hline & $\mathrm{HF}$ & 112.4 & 120.7 & 124.2 & 124.1 & 127.7 & & & & \\
\hline
\end{tabular}

${ }^{1}$ Data presented are least-square means with standard error of means (SEM) and represent measurements taken during ISS ( $n=8$ to 9).

${ }^{2}$ ATTD $=$ apparent total tract digestibility.

${ }^{3} \mathrm{PD}=$ protein deposition $(\mathrm{N}$ retained $\times 6.25)$.

${ }^{4} \mathrm{SID}=$ standardized ileal digestible. 
of DF and no interaction observed. This linear increase in PD with increasing Thr suggests that to achieve maximum PD during ISS, higher dietary Thr will be required. Further, this is related to the systemic effect of LPS injection, which is expected to increase Thr requirement for PD due to the repartitioning of AA towards maintaining an immune response and prioritization of immune function over growth (Reeds et al., 1994; Obled, 2003; Munasinghe et al., 2017). Although statistically we cannot compare the pre-ISS period to the ISS period, $\mathrm{N}$ retained and PD were numerically less in pigs fed LF diets when ISS was present compared to the values for pigs fed LF diets without ISS. This confirms that ISS independently reduces $\mathrm{N}$ retention and PD. During ISS, high DF did not affect $\mathrm{N}$ retention and $\mathrm{PD}(P>0.05$; Table 5). Similarly, comparing numerically between high HF during pre-ISS with HF during ISS, PD was numerically decreased during the ISS period. However, we cannot exactly separate the singular effects of ISS and HF on PD, but suggests that high DF and ISS do not act additively to further reduce $\mathrm{N}$ retention and PD (Table 6).

\section{Threonine Requirement for ISS and Fiber}

Broken-line regression can be used to analyze nutrient dose-response data using either linear or quadratic functions to estimate a break point which is interpreted as the nutrient requirement (Robbins et al., 2006). In the current study, dose response data were analyzed using both linear and quadratic break-point model; however, quadratic break-point model provided the best fit to the data according to the coefficient of determination $\left(R^{2}\right)$ and so only results from the this model are presented.

When no ISS was present, we observed an increase in the estimate of Thr requirement for PD in the HF-fed pigs compared to the LF-fed pigs. The Thr requirement for LF diets for maximum PD was estimated at $0.68 \% \operatorname{SID}\left(R^{2}=0.88\right)$ and for HF diets at $0.78 \% \operatorname{SID}\left(R^{2}=0.99\right)$ as shown in Fig. $2 \mathrm{~A}$ and $\mathrm{B}$, respectively. The estimated $\mathrm{Thr}$ requirement in $\mathrm{LF}$ diets was higher than $0.61 \%$ SID Thr suggested by NRC (2012) for pigs of 25 to $50 \mathrm{~kg} \mathrm{BW}$ but lower than the value estimated by Mathai et al. (2016) at $0.72 \%$ SID Thr required to optimize growth performance in gilts between 25 and $50 \mathrm{~kg}$ fed LF diets. Similarly, Zhang et al. (2013) estimated 0.64\% SID Thr requirement in 22 to $50 \mathrm{~kg}$ when fed LF diets with low crude protein levels. The SID Thr required to maximize PD in an HF diet was estimated at $0.78 \%$ in the present study and suggests that high DF increases Thr requirement, which is consistent with Mathai et al. (2016) who estimated $0.77 \%$ SID Thr required to optimize growth performance in gilts fed a high DF. The NRC (2012) acknowledges the effect of high DF on threonine requirement and therefore provides an adjustment in requirements when HF diets are fed to pigs. Others have reported reduction in growth performance or PD and effects on Thr when feeding HF diets (Zhu et al., 2005; Libao-Mercado et al., 2006; Myrie et al., 2008).

During ISS period, Thr requirement for LF diets was estimated at $0.76 \%$ SID (Fig. 3A), which was higher than the $0.68 \%$ SID Thr estimated when ISS was absent, this suggests that ISS increases requirement for Thr to maximize $\mathrm{PD}$. As far as we know, this is the first study to quantify the effect of ISS on Thr requirements in pigs for PD. Some studies have observed changes in immune status (Li et al., 1999) and growth performance of pigs when immune challenged (Zhang et al., 2013) and graded levels of Thr are fed. Others have quantified requirement for Met to Met + Cys ratio (Litvak et al., 2013), Leu requirements (Rudar et al., 2016), and utilization efficiency of tryptophan for PD (de Ridder et al., 2012). These studies used the LPS model to initiate ISS as used in the present study and have all reported that ISS increases requirement for the AA under investigation. Litvak et al.

Table 6. Linear and quadratic relationship of dietary threonine and fiber on PD ( g/d)

\begin{tabular}{|c|c|c|c|c|c|c|c|c|c|}
\hline & & \multicolumn{6}{|c|}{$\mathrm{SID}^{1}$ threonine, $\%$} & \multicolumn{2}{|c|}{$P$-value } \\
\hline & & 0.49 & 0.57 & 0.65 & 0.72 & 0.81 & SEM & Linear & Quad \\
\hline \multirow[t]{2}{*}{ Pre-ISS $^{2}$} & $\mathrm{LF}^{3}$ & 119.7 & 131.5 & 134.4 & 140.0 & 133.2 & 2.88 & $<0.01$ & $<0.01$ \\
\hline & $\mathrm{HF}^{4}$ & 121.3 & 126.6 & 131.4 & 133.3 & 133.3 & 3.04 & $<0.01$ & 0.24 \\
\hline \multirow[t]{2}{*}{ ISS } & LF & 114.4 & 123.2 & 120.7 & 131.1 & 124.9 & 4.12 & $<0.05$ & 0.27 \\
\hline & $\mathrm{HF}$ & 112.5 & 120.7 & 124.2 & 123.9 & 127.3 & 3.80 & $<0.05$ & 0.36 \\
\hline
\end{tabular}

${ }^{1} \mathrm{SID}=$ standardized ileal digestible.

${ }^{2} \mathrm{ISS}=$ immune system stimulation.

${ }^{3} \mathrm{LF}=$ low fiber diet.

${ }^{4} \mathrm{HF}=$ high fiber diet. 

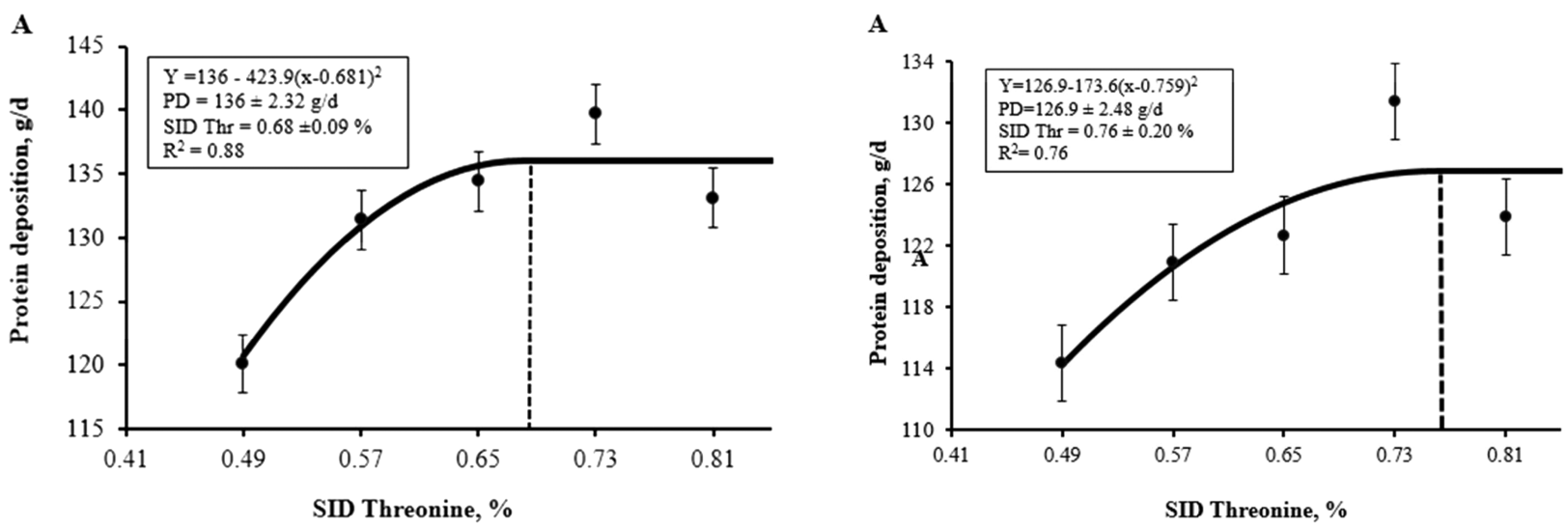

B

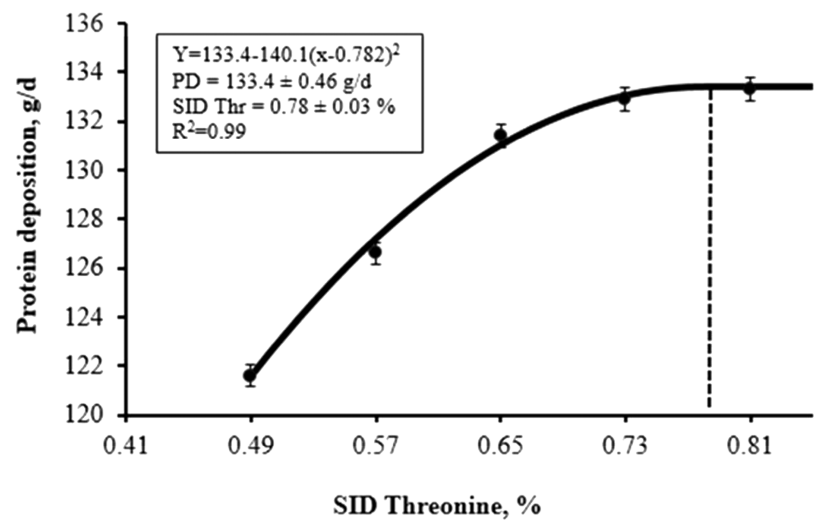

Figure 2. The quadratic break-point model analysis estimates during the pre-ISS period for low fiber (LF) (A) and high fiber (HF) (B). LF diets show a breakpoint at $0.68 \%$ SID Thr for maximum protein deposition (PD) at $136 \mathrm{~g} / \mathrm{d}$. HF diets show a breakpoint at $0.78 \%$ SID $\mathrm{Thr}$ for maximum PD at $133 \mathrm{~g} / \mathrm{d}$.

(2013) reported an increase in Met to Met + Cys ratio during an LPS challenge. Similarly, de Ridder et al. (2012) reported a reduction in Trp utilization efficiency for PD in growing pigs challenged with LPS. Therefore, the increase in Thr requirement estimated in the present study during ISS agrees with the previous reports. Of the AA, Glu, Arg, $\mathrm{Thr}$, and aromatic and sulfur AA are of particular importance during immune challenge (Reeds and Jahoor, 2001). Threonine is especially important for the synthesis of many acute phase proteins and immunoglobulins during immune response (Reeds et al., 1994; Li et al. 2007) explaining the increase in Thr requirement for PD with ISS. Furthermore, Rakhshandeh et al. (2013) demonstrated increased intestinal MUC2 expression, abundant in Thr, following systemic LPS challenge in pigs.

In the present study, we also evaluated the combined effects of feeding high DF to pigs when ISS was present on Thr requirement for PD. As shown in Fig. 3B, estimated Thr requirement for PD was lower $(0.72 \%$ SID Thr) compared to the estimates of $0.78 \%$ SID Thr required for PD with

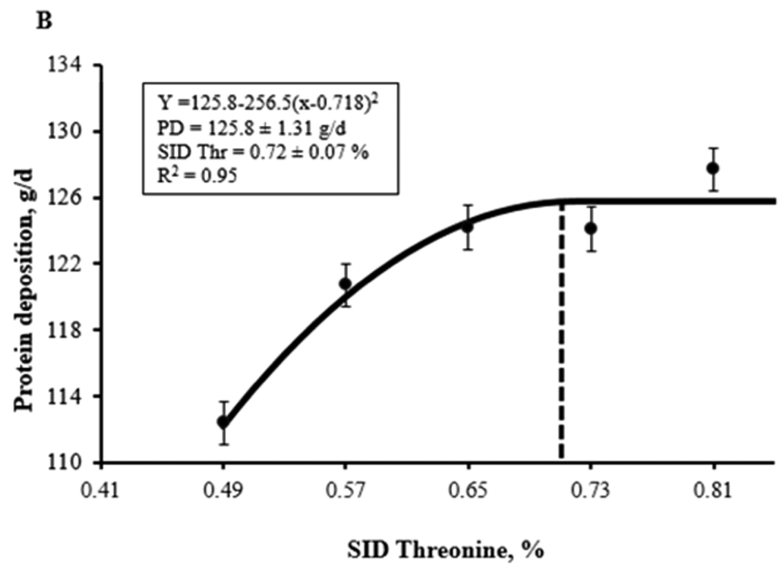

Figure 3. The quadratic break-point model analysis estimate during the ISS period for LF (A) and HF (B). LF diets show a breakpoint at $0.76 \%$ SID Thr for maximum PD at $127 \mathrm{~g} / \mathrm{d}$. HF diets show a breakpoint at $0.72 \%$ SID Thr for maximum PD at $126 \mathrm{~g} / \mathrm{d}$.

feeding high DF diets when ISS was absent, and $0.76 \%$ SID Thr required for PD with feeding LF diets during ISS. We hypothesized that feeding high DF diets with ISS would have an additive effect on the amount of Thr required to maximize PD; however, the results suggest a non-additive effect. The mechanisms related to this observation are not clear but could be related to the effect of high DF increasing mucous secretion mediated by a local physiological inflammatory response to the DF such that LPS injection did not contribute to any further inflammatory response in intestinal mucosa and hence the need for increased $\mathrm{Thr}$ requirement to support added mucous secretion. We further hypothesize that the injection of LPSinduced some physiological inflammation in the intestine when pigs were fed the LF diets, but in case of the high DF diets, the intestine is refractory to the influence of systemic LPS challenge. It should also be noted that the plateau, and therefore the requirement, in HF fed pigs during ISS is based on few data points and therefore could be higher. 


\section{CONCLUSIONS}

In the present study, we have confirmed that high DF reduces $\mathrm{N}$ retention and PD efficiency and further quantified that SID Thr of $0.78 \%$ is required to maximize $\mathrm{PD}$ when feeding pigs high DF. We also quantify for the first time the effect of ISS on Thr requirement for $\mathrm{PD}$, which translates to $0.76 \%$ SID $\mathrm{Thr}$ required to maximize $\mathrm{PD}$ in growing pigs from 25 to $50 \mathrm{~kg}$. Further, the present study shows that combining the effects of high DF and ISS did not additively increase Thr required to maximize PD, suggesting that DF could mask the ISS effects on Thr required for maximum PD. The mechanisms explaining the lack of additive effects require clarification.

Although there are some variations in these estimates as reported by other authors, these variations could be partly accounted for by the differences in the response parameters (e.g., PD, ADG) measured and the type and concentration of fiber used in these studies as well as the regression models used to analyze and interpret the data. However, this finding is important because of the increasing use of co-products in swine diets and the resulting increase in DF. Therefore, understanding changes and defining Thr requirement under the range of conditions experienced commercially will lead to improved nutritional programs that will increase production efficiency and profitability and reduce the environmental impact of pork production.

\section{ACKNOWLEDGMENTS}

The authors would like to thank the staff and students at the Prairie Swine Centre Inc., the staff of the Canadian Feed Research Centre, and the Swine Nutrition research group at the University of Saskatchewan for their support.

\section{LITERATURE CITED}

AOAC, Int. 2007. Official methods of analysis of AOAC International. Gaithersburg, MD: AOAC International.

Blank, B., E. Schlecht, and A. Susenbeth. 2012. Effect of dietary fibre on nitrogen retention and fibre associated threonine losses in growing pigs. Arch. Anim. Nutr. 66:86-101. doi:10.1080/1745039x.2012.663669

Canadian Council on Animal Care (CCAC). 2009. Guidelines on the care and use of farm animals in research, teaching and testing. Ottawa, ON: CCAC.

Christoffersen, B. Ø., S. J. Jensen, T. P. Ludvigsen, S. K. Nilsson, A. B. Grossi, and P. M. Heegaard. 2015. Age- and sex-associated effects on acute-phase proteins in Göttingen minipigs. Comp. Med. 65:333-341.

Dilger, R. N., J. S. Sands, D. Ragland, and O. Adeola. 2004. Digestibility of nitrogen and amino acids in soybean meal with added soyhulls. J. Anim. Sci. 82:715-724. doi: $10.2527 / 2004.823715 \mathrm{x}$

Doumas, B. T., W. A. Watson, and H. G. Biggs. 1971. Albumin standards and the measurement of serum albumin with bromcresol green. Clin. Chim. Acta. 31:87-96. doi:10.1016/0009-8981(71)90365-2

Emiola, I. A., F. O. Opapeju, B. A. Slominski, and C. M. Nyachoti. 2009. Growth performance and nutrient digestibility in pigs fed wheat distillers dried grains with solubles-based diets supplemented with a multicarbohydrase enzyme. J. Anim. Sci. 87:2315-2322. doi:10.2527/ jas.2008-1195

Gabay, C., and I. Kushner. 1999. Acute-phase proteins and other systemic responses to inflammation. N. Engl. J. Med. 340:448-454. doi:10.1056/NEJM199902113400607

Gruys, E., M. J. Toussaint, T. A. Niewold, and S. J. Koopmans. 2005. Acute phase reaction and acute phase proteins. J. Zhejiang Univ. Sci. B 6:1045-1056. doi:10.1631/jzus.2005.B1045

Heegaard, P. M., J. Klausen, J. P. Nielsen, N. GonzálezRamón, M. Piñeiro, F. Lampreave, and M. A. Alava. 1998. The porcine acute phase response to infection with Actinobacillus pleuropneumoniae. Haptoglobin, C-reactive protein, major acute phase protein and serum amyloid A protein are sensitive indicators of infection. Comp. Biochem. Physiol. B Biochem. Mol. Biol. 119:365-373. doi:10.1016/S0305-0491(97)00362-3

Hultén, C., E. Johansson, C. Fossum, and P. Wallgren. 2003. Interleukin 6, serum amyloid $\mathrm{A}$ and haptoglobin as markers of treatment efficacy in pigs experimentally infected with Actinobacillus pleuropneumoniae. Vet. Microbiol. 95:75-89. doi:10.1016/S0378-1135(03)00136-6

Jansman A. J. M, W. Smith, P. Van Leeuwen, and M. Rademacher. 2002. Evaluation through literature data of the amount and amino acid composition of basal endogenous crude protein at the terminal ileum of pigs. Anim. Feed Sci. Technol. 98:49-60. doi:10.1016/ S0377-8401(02)00015-9

Kluess J., S. Kahlert, P. Panther, A. K. Diesing, C. Nossol, H. J. Rothkötter, S. Kersten, and S. Dänicke. 2015. Systemic E. coli lipopolysaccharide but not deoxynivalenol results in transient leukopenia and diminished metabolic activity of peripheral blood mononuclear cells ex vivo. Mycotoxin Res. 31:41-50. doi: 10.1007/s12550-014-0212

Knudsen B., and K. E. Hansen. 1991. Gastrointestinal implications in pigs of wheat and oat fractions. 1. Digestibility and bulking properties of polysaccharides and other major constituents. Br. J. Nutr. 65:217-232. doi:10.1079/ BJN19910082

Knudsen E. K. B., M. S. Hedemann, and H. N. Laerke. 2012. The role of carbohydrates in intestinal health of pigs. Anim. Feed Sci. Technol. 173:41-53. doi:10.1016/j. anifeedsci.2011.12.020

Kvidera, S. K., E. A. Horst, E. J. Mayorga, M. V. SanzFernandez, M. Abuajamieh, and L. H. Baumgard. 2017. Estimating glucose requirements of an activated immune system in growing pigs. J. Anim. Sci. 95:5020-5029. doi:10.2527/jas2017.1830

Lan, Y., F. O. Opapeju, and C. M. Nyachoti. 2008. True ileal protein and amino acid digestibilities in wheat dried distillers' grains with solubles fed to finishing pigs. Anim. Feed Sci. Technol. 140: 155-163. doi:10.1016/j. anifeedsci.2007.02.004

de Lange, C. F., A. M. Gillis, and G. J. Simpson. 2001. Influence of threonine intake on whole-body protein deposition and 
threonine utilization in growing pigs fed purified diets. J. Anim. Sci. 79:3087-3095. doi:10.2527/2001.79123087x

Le Floc'h, N., D. Melchior, and C. Obled. 2004. Modifications of protein and amino acid metabolism during inflammation and immune system activation. Livest. Prod. Sci. 87:37-45. doi:10.1016/j.livprodsci.2003.09.005

Li, D., X. Changting, Q. Shiyan, Z. Jinhui, E. W. Johnson, and P. A. Thacker. 1999. Effects of dietary threonine on performance, plasma parameters and immune function in growing pigs. Anim. Feed Sci. Technol. 78:179-188. doi:10.1016/S0377-8401(99)00005-X

Li, P., Y. L. Yin, D. Li, S. W. Kim, and G. Wu. 2007. Amino acids and immune function. Br. J. Nutr. 98:237-252. doi:10.1017/S000711450769936X

Libao-Mercado, A. J., S. Leeson, S. Langer, B. J. Marty, and C. F. de Lange. 2006. Efficiency of utilizing ileal digestible lysine and threonine for whole body protein deposition in growing pigs is reduced when dietary casein is replaced by wheat shorts. J. Anim. Sci. 84:1362-1374. doi: $10.2527 / 2006.8461362 x$

Libao-Mercado, A. J., C. L. Zhu, M. F. Fuller, M. Rademacher, B. Sève, and C. F. M. de Lange. 2007. Effect of feeding fermentable fiber on synthesis of total and mucosal protein in the intestine of the growing pig. Livest. Sci. 109:125128. doi:10.1016/j.livsci.2007.01.116

Lindberg, J. E. 2014. Fiber effects in nutrition and gut health in pigs. J. Anim. Sci. Biotechnol. 5:15. doi:10.1186/2049-1891-5-15

Litvak, N., A. Rhakhshandeh, J. K. Htoo, and C. F. M. de Lange. 2013. Immune system stimulation increases the optimal dietary methionine to methionine plus cysteine ratio in growing pigs. J. Anim. Sci. 91:4188-4196. doi: 10.2527/jas.2012-6160

Llames, C. R., and J. Fontaine. 1994. Determination of amino acids in feeds: collaborative study. J. AOAC Int. 77:1362-1366.

Makimura, S., and N. Suzuki. 1982. Quantitative determination of bovine serum haptoglobin and its elevation in some inflammatory diseases. Nihon Juigaku Zasshi. 44:15-21. doi:10.1292/jvms1939.44.15

Mathai, J. K., J. K. Htoo, J. E. Thomson, K. J. Touchette, and H. H. Stein. 2016. Effects of dietary fiber on the ideal standardized ileal digestible threonine:lysine ratio for twenty-five to fifty kilogram growing gilts. J. Anim. Sci. 94:4217-4230. doi:10.2527/jas.2016-0680

Métayer, S., I. Seiliez, A. Collin, S. Duchêne, Y. Mercier, P. A. Geraert, and S. Tesseraud. 2008. Mechanisms through which sulfur amino acids control protein metabolism and oxidative status. J. Nutr. Biochem. 19:207-215. doi:10.1016/j.jnutbio.2007.05.006

Munasinghe, L. L., J. L. Robinson, S. V. Harding, J. A. Brunton, and R. F. Bertolo. 2017. Protein synthesis in mucin-producing tissues is conserved when dietary threonine is limiting in piglets. J. Nutr. 147:202-210. doi:10.3945/ jn. 116.236786

Myrie, S. B., R. F. Bertolo, W. C. Sauer, and R. O. Ball. 2008. Effect of common antinutritive factors and fibrous feedstuffs in pig diets on amino acid digestibilities with special emphasis on threonine. J. Anim. Sci. 86:609-619. doi:10.2527/jas.2006-793

National Research Council (NRC). 2012. Nutrient requirements of swine. 11th rev. ed. National Academies Press,
Washington, DC.

Obled, C. 2003. Amino acid requirements in inflammatory states. Can. J. Anim. Sci. 83:365-374. doi:10.4141/A03-021

Pieper, R., S. Kröger, J. F. Richter, J. Wang, L. Martin, J. Bindelle, J. K. Htoo, D. von Smolinski, W. Vahjen, J. Zentek, et al. 2012. Fermentable fiber ameliorates fermentable protein-induced changes in microbial ecology, but not the mucosal response, in the colon of piglets. J. Nutr. 142:661-667. doi:10.3945/jn.111.156190

Rakhshandeh, A., and C. F. de Lange. 2012. Evaluation of chronic immune system stimulation models in growing pigs. Animal 6:305-310. doi:10.1017/S1751731111001522

Rakhshandeh, A., T. E. Weber, J. C. M. Dekkers, C. K. Tuggle, B. J. Kerr, and N. K. Gabler. 2013. Impact of systemic immune system stimulation on intestinal integrity and function in pigs. FASEB J. 27(Suppl. 1):867-2.

Reeds, P. J., C. R. Fjeld, and F. Jahoor. 1994. Do the differences between the amino acid compositions of acutephase and muscle proteins have a bearing on nitrogen loss in traumatic states? J. Nutr. 124:906-910. doi:10.1093/ jn/124.6.906

Reeds. P. J., and F. Jahoor. 2001. The amino acid requirements of disease. Clin. Nutr. 1:15-22. doi:10.1054/ clnu.2001.0402

de Ridder, K., C. L. Levesque, J. K. Htoo, and C. F. de Lange. 2012. Immune system stimulation reduces the efficiency of tryptophan utilization for body protein deposition in growing pigs. J. Anim. Sci. 90:3485-3491. doi:10.2527/ jas.2011-4830

Robbins, K. R., A. M. Saxton, and L. L. Southern. 2006. Estimation of nutrient requirements using broken-line regression analysis. J. Anim. Sci. 84(Suppl.):E155-E165. doi:10.2527/2006.8413_supplE155x

Rudar, M., C. L. Zhu, and C. F. de Lange. 2016. Effect of supplemental dietary leucine and immune system stimulation on whole-body nitrogen utilization in starter pigs. J. Anim. Sci. 94:2366-2377. doi:10.2527/jas.2015-0120

Rutherford, S. M., and P. J. Moughan. 2000. Developments in the determination of protein and amino acids. In: P. J. Moughan, M. W. A. Verstegen, and M. I. VisserReyneveld, editors, Feed evaluation: principles and practice. Wageningen Pers, Wageningen, the Netherlands. p. 45-64.

Stein, H. H., N. L. Trottier, C. Bellaver, and R. A. Easter. 1999. The effect of feeding level and physiological status on total flow and amino acid composition of endogenous protein at the distal ileum in swine. J. Anim. Sci. 77:1180-1187. doi:10.2527/1999.7751180x

Van Keulen, J. V., and B. A. Young. 1977. Evaluation of acid insoluble ash as a natural marker in ruminant digestibility studies. J. Anim. Sci. 44:282. doi:10.2527/jas1977.442282x

Zhang, G. J., C. Y. Xie, P. A. Thacker, J. K. Htoo, and S. Y. Qiao. 2013. Estimation of the ideal ration of standardized ileal digestible threonine to lysine for growing pigs $(22-50 \mathrm{~kg})$ fed low crude protein diets supplemented with crystalline amino acids. Anim. Feed. Sci. Technol. 180:8391. doi:10.1016/j.anifeedsci.2013.01.006

Zhu, C. L., M. Rademacher, and C. F. de Lange. 2005. Increasing dietary pectin level reduces utilization of digestible threonine intake, but not lysine intake, for body protein deposition in growing pigs. J. Anim. Sci. 83:1044 1053. doi: $10.2527 / 2005.8351044 x$ 